\title{
On the Two Truths Theory of Klong-rdol Bla-ma
}

\section{Kōichi Furusaka}

The Theg-chen-gyi mngon-pa' $i$ sde-snod las byung-ba'i dBu-ma'i skor-gyi ming-gi rnam-grangs (TH. No. 6540 : Explanation of the canons and treatises of the Mãdhyamika school, dealing with technical terms found in them) is a kind of the summary of philososhical systems which was written by Klong-rdol blama Ngag-dbang blo-bzang (born 1719).

Its text has 21 folios, but the latter half of it (12a3-21a4) is the summary of Tibetan Buddhism entitled 'Bod gangs-can-gyi lta-ba'i grub-mtha' ragsrim ngo-sprod" (the sketchy introduction of Tibetan philosophical systems).

In the first half, the two truths theories of Indian Buddhism are summarized. The schools treated are Vaibhāṣika, Sautrāntika, Vijñānavāda, Mādhyamika-Svātantrika and Mādhyamika-Prāsangika.

(I) Firstly Klong-rdol bla-ma interprets the two truths theoty of Vaibhāșikas.

"Definiens (lakșana: mtshan-nyid) of ultimate truth (paramartha-satya) is that though someone destroys or mentally denies the other thing, the idea which it takes is not lost, and cognized as dharma." ${ }^{1)}$

"Definienda (laksya : mtshan-gzhi) are the atoms which are partless in directions, indivisible momentary noetic events, cessation through wisdom (pratisamkhyanirodha) and cessation in a natural way (apratisamkhyanirodha).

Also (another) definiens of the ultimate truth is that it is to be grasped as the reality through knowledge of designation without passion. Definienda are as same as before.

"Definiens of conventional truth (samvrti-satya) is that when someone destroys or mentally denies the other thing, the idea which it takes is lost, and cognized as dharma.

Definienda are such as a bottle or water in a bottle.

Also, another definiens of conventional truth it is to be grasped as the reality through knowledge of designation with passion. Definieda are as same as before." 
(17) On the Two Truths Theory of Klong-rdol Bla-ma (K. Furusaka)

(II) Next, Klong-rdol bla-ma interprets the two truths theoty of Sautrāntikas.

"Definiens of ultimate truth is that the idea is attained as the appearance on an ultimate perception. Definiens of conventional truth is that the idea is attained as the appearance on everyday understanding. Also, they can be summarized as the attained to perceptual appearance and the attained to appearance on understanding."

(III) Next, the two truths theory according to the view of Vijñanavādins is interpreted. Then firstly conventional truths are explained.

"Definiens of a conventional truth is the cognition of dharma from which passions may be born. Definienda are all things which have own-characterisic of the unfulfilled (nature) and all understandings of common characteristics.

Definiens of ultimate truth is the dharma of which cognition arrives at the extreme limit (paryanta-gata) by means of path of purification (viśuddhi-mārga). The ultimate truth and the fulfilled (parinispanna) (nature) have equal meaning.

Here, some one says that (there are two kinds of the fulfilled); i. e. the fulfilled concerning selflessness of person and the fulfilled concerning selflessness of dharma: The first is similar to the fine selflessness of person (gang-zag-gi bdagmed phra-mo), and the second the fine selflessness of dharma (chos-kyi bdag-med phra-mo lta-bu'o).

But some one says that if (something) is the fulfilled, then it must be the fulfilled concerning the selflessness of dharma. He keeps in mind that definienda of the ultimate truth are the śünyatā (in the sense) that the marks of matter and apprehender of the matter are empty because of (depending to each) other things; the śunyatā (in the sense) that matter dependent on external object is empty; that (anything) is not to be established and does not exist really on its own character as the basis of affection discriminating matter and apprehender of the matter; that (anything) is not to be established and does not exist really on its own character as the basis into which the word "matter, matter" enters; that the constructed is not to be established and does not exist really on its own character; that the constructed on the own-being of dharmas is not to be established and does not exist really on its own character; that the constructed of the constructed on the distinction of dharmas is not to be established and does not exist really on its own character.

It is the synonym of the names of emptiness (śünyatā), suchness (tathatā), 
On the Two Truths Theory of Klong-rdol Bla-ma (K. Furusaka) the reality-limit (bhütakoți), the realm of the signless (animitta), the realm of all dharmas (dharma-dhatu), reality (tattva), the fine selflessness of dharma (dharma-nairätmya), the events of the ultimate truth of which cognition arrives at the extreme limit (paryanta-gata) by means of path of purification (višuddhimärga).

(IV) Next, the two truths according to the view of Mādhyamika-Svātantrikas are interpreted.

"Definiens of ultimate truth is that it is to be understood by the exalted knowledge of all aspects which understands the modes as they are in themselves in the manner that dualistic appearances disappear, but it is not to be understood after the manner of that which has dualistic appearance by that knowledge ( $j i$ lta-ba rtogs-pa'i rnam-mkhyen gyis gnyis-snang dang bcas-pa'i tshul-gyi rtogs-par bya-ba ma yin-par/ des gnyis snang nub-pa'i tshul gyis rtogs-par bya-ba).

Also, another definiens of ultimate truth is that it is to be understood in the manner that dualistic appearances disappear by perception as a means of cognition which actually understands the nature of thing, and it is understood in the manner that any thing is established.

Its definiendum is similar to the sixteen or eighteen śunyată.

Definiens of conventional truth is that it exists in the category of the understood after the manner of that which has dualistic appearance by means of the exalted knowledge of all aspects which understands the varieties of phenomenal aspect as they are in totality ( $j i$ snyed-pa rtogs-pa'i rnam-mkhyen gyis gnyis-snang dang bcas-pa'i tshul gyis rtogs-par bya-ba'i rigs su gnas-pa).

Also, another definiens of conventional truth is that it exists in the category of the understood after the manner of that which has dualistic appearance by perception as a means of cognition which actually understands the nature of thing. This and the existence of un-ultimate truth (don-dam-pa bden-pa ma yin-pa' $i$ yod$p a)$ are synonimous.

"And also, according to the view of the Svantantrikas, there are two kinds (of the conventional truth); i.e. the unreal conventional truth (mithya-samvrtisatya: log-pa'i kun-rdzob) and the real conventional truth (tathya-samvrtisatya: yangdag kun-rdzob).

Definiens of the unreal conventional truth is that it can be understood by rough worldly beings, although it is not established as appearance in the understanding 


\section{(19) On the Two Truths Theory of Klong-rdol Bla-ma (K. Furusaka)}

which makes his own perception the object. Its definiendum is such as the image of shape in a mirror.

Definiens of the real conventional truth is that it can not be understood by rough worldly beings, moreover it is not (?) established as appearance in the understanding which makes his own perception the object (rang snang yul du byedpa'i blo la snang-ba ltar ma grub-pa [sic]'jig-rten rang 'ga'-bas rtogs mi nus-pa yang-dag kun-rdzob kyis mtshan-nyid). Its definienda are such as bottle or pillar." Here Klong-rdol bla-ma quotes Jñānagarbha's Satyadvayavibhañga-kārikā (TH. 3881 : SVK) 12.

"Just it is said in the Two truths of Mādhyamika as follows :

Since they are able and unable

To perform functions as they appear,

The division of real and unreal

Conventionalities is made."2) (Dg. ed. fol. 2a4)

(V) Lastly the two truths according to the view of Prāsangikas are interpreted.

"Definiens of ultimate truth is that when the means of right knowledge itself to examine the extreme limit becomes to the right knowledge in you, and it has been obtained as the purpose. Its definienda are the fine selflessness of person, the fine selflessness of dharma and the eighteen śünyatãs.

Definiens of conventional truth is that whatever purpose itself which is obtained by a means of knowledge to examine convention (vyavahāra) becomes the means of conventional knowledge in you. Its definienda are all judgements and things which are not the ultimate truth."

And here Klong-rdol bla-ma quotes the similar definiens of the two truths shewn by 1Cang-skya rol-pa'i rdo-rje (1717-86). So it seems that Klong-rdol bla-ma followed lCang-skya's theory as his junior in the same dGe-lugs-pa school.

Now I wish to inquire into the above-mentioned two truths theoy of the Mādhyamika Svātantrika.

In the Bodhisattvabhūmi (BBh) in Yogācārabhūmi, the two truths are suggested with the expression "yāvad bhāvikatā" and "yathāvad bhāvikatā". These words are found in the above-mentioned context of Svātant- 
On the Two Truths Theory of Klong-rdol Bla-ma (K. Furusaka)

rika's theory. BBh. chap. 4 says,

"What is knowledge of reality? Concisely, there are two sorts : (1) that sort which consists of [knowing] the noumenal aspect of dharmas, or the true state of dharmas as they are in they are in themselves; and (2) that sort which consists of [knowing] the phenomenal aspect of dharmas, as they are in totality. In short, knowledge of reality should be understood as [knowledge of] "dharmas as they are, and as they are in totality." ${ }^{3)}$

The Yu k'ie louen ki (Yugaronki: Taisho. No. 1828), which is the only commentary upon the whole of the Yogācārabhümi composed by a Korean monk Tonrin who flourished in 'T'ang dinasty, explicates that the essence of (1) the yathāvad-bhāvikatā is the paramärtha-satya, the parinispannasvabhäva, on the contrary the essence of (2) the yāvad-bhāvikata is the lokasamvrti-satya, the paratantra-svabhāva.

Similarly the Yogācārabhūmau Bodhisattvabhūmi-vyākhā written by Sāgaramegha relates the yāvad-bhāvikatā and the yathāvadbhāvikatā respectly to the conventional knowledge (samvrti-jñana) and the ultimate knowledge (paramārtha-jñāna) or the paramārtha-satya. (Dg. ed., fol. 55a3)

On the other side, Bhāvaviveka who founded the Mādhyamika-Svātantrika school analysed the paramärth-satya into two levels. The first is the paramātha itself and the second is named "the conventional (sāmketika)" paramārtha by Avalokitavrata in the Prajnāpradīpațikā (TH. No. 3859).

But Bhāvaviveka did not divide the samvorti-satya into any levels. Not. withstanding he used the term"tathya-samvrti" in Madhyamakahrdayakā. rikā (MHK) and Tarkajvālä (TJ), there he did not specify the counterpart concept to it. But in the Madhyamārthasamgraha (TH. No. 3857 : MAS) which is assigned to Bhāvaviveka or Bhavya (Legs-ldan byed), the author divides the samvrti into the mithya-samvrti and the bhüta-(or tathya-) samorti. This difference seems to support the hypothesis that Bhāvaviveka who composed Prajñapradipa, MHK and TJ and "Bhāvaviveka" or "Bhavya" who composed MAS are not the same one."

In MAS not only the two samvrtis are shown as the unreal samvrti (mithyā-samvrti) and the real samvrti (tathya-samvrt?), but also the ultimate 
(21) On the Two Truths Theory of Klong-rdol Bla-ma (K. Furusaka)

is divided into two sorts; paryāya-paramārtha (the synonymous ultimate) and aparyāya-p. (the un-synonymous u.). The former has also two sorts; one is the logic and the other is the negative in regard of origination. But later on, this point of the ultimate became not to be emphasized in Svātantrikas. Jñānagarbha divided also the sampvrti satya (conventional truth) into two sorts as aforementioned.

Thus Klong-rdol bla-ma states the two sorts of samvrti as the characteristics of Svātantrika view. Bu the does not also mention the two levels of the ultimate. Moreover it is noteworthy that he applies the two realities of the Yogācăra, i.e. yathāvad-bhāvikatā and yāvad-bhāvikatā respectly to paramärtha and samiorti. So it seems that in later times the Svātantrika view about the two-truths came in effect to be represented as more nearer to the views of Jñannagarbha and Yogācāra rather than to the view of Bhāvaviveka.

1) Abhidharmakośa (VI 4); H.V. Guenther: Buddhist Philosophy in Theory and Practice (Berkeley, 1972), p. 54-5. Cf. A. Klein : Knowledge and Liberation (Ithaca, 1986) p. 34 .

2) D.S. Lopez; A Study of Svātantrika (Ithaca, 1987), p. 207.

3) Bodhisattvabhumi, Ed. by N. Dutt (Patna, 1966), p. 25; J.D. Willis, On Knowing Reality (New York, 1979) p. 69.

4) Cf. Yasunori Ejima: Chugan Shiso No Tenkai-Bhãvaviveka Kenkyu (Shunjusha, Tokyo,' 1980) p. $18 f$.

〈Key Words〉 Klong-rdol bla-ma, two truths, Svātantrika

(Prof., Osaka Kyoiku University)

NEW PUBLICATION

The Legend of King Asoka

by

Benoytosh Bhattacharyya

Motilal Banarsidass, Delhi, 1989 